\title{
Geological, Mineralogical and Geochemical Studies of Pyrite Deposits in the Eastern Part of Douala Sub-Basin (Cameroon, Central Africa)
}

\author{
Gilbert François Ngon Ngon ${ }^{*}$, Pierre Stève Abomo', Michel Bertrand Mbog1, \\ André Mbabi Bitchong², Joël Simon Mbaï1, Thérèse Valérie Ngonlep Minyemeck, \\ Rose Yongue Fouateu ${ }^{2}$ \\ ${ }^{1}$ Laboratory of Geosciences and Environment, Department of Earth Sciences, Faculty of Science, University of \\ Douala, Douala, Cameroon \\ ${ }^{2}$ Laboratory of Applied Geology-Metallogeny, Department of Earth Sciences, Faculty of Science, University of \\ Yaounde I, Yaounde, Cameroon \\ Email: "gngonngon@yahoo.fr
}

Received 23 June 2015; accepted 25 August 2015; published 28 August 2015

Copyright (C) 2015 by authors and Scientific Research Publishing Inc.

This work is licensed under the Creative Commons Attribution International License (CC BY). http://creativecommons.org/licenses/by/4.0/

\section{Open Access}

\section{Abstract}

Pyrite deposit of pK27, Douala sub-basin (Cameroon, Central Africa) was studied in a tropical forest setting physically and using X-ray diffraction and X-ray fluorescence spectrometry (XRF) in order to characterize the mineralization for his industrial utilization. The sedimentary materials from the pyrite deposit were grouped into five (05) main lithofacies, including four claystone facies and one conglomeratic facies. The mineralization occurs along the low slopes of valleys in light grey claystone facies situated on the bottom of outcrops with 80 to $200 \mathrm{~cm}$ thickness. The particle size distribution of clayey materials host rocks shows that they are essentially constituted of clay and silts fractions. However, their Sorting index (So) more than 4.5 corresponds to poorly sorted sediments and the torrential type; whereas their Coefficient of asymmetry (A) more than 1 indicates that the sorting is carried out towards fine particles. Macroscopically, pyrite in these materials is in crumbly and consolidated piles with aggregate pyrites in oolithic concretions, and globular, cubic, octaedric, massive and fossiliferous forms. The mineralogical compositions of these clayey materials indicate that they are essentially kaolinitic and illitic, followed by goethite, quartz, pyrite, halloysite, anatase and rutile with hematite as accessory minerals. Pyrite in sand fractions is associated with kyanite, grenat, rutile, diopside, muscovite and tourmaline the minerals which recognize the regional metamorphism. However, the specific chemical signature of $\mathrm{SO}_{3}$ content high in clayey materials and abundant $\left(50.86 \%-57.64 \% \mathrm{SO}_{3}\right)$ in pyrite is characteristic of the $\mathrm{pK} 27 \mathrm{py}$ ${ }^{*}$ Corresponding author. 
ritic formations in the eastern part of Douala sub-basin. Moreover, the Co:Ni ratios of pyrites approximately 0.25 to 0.8 are characteristic of sedimentary pyrites and also suggest an anoxic environment.

\section{Keywords}

Douala Sub-Basin, Geochemical, Geological, Mineralogical, Pyrite Deposits

\section{Introduction}

Pyrite is a mineral widespread in almost all geological environments. Several studies have been carried out on pyrite occurrences in sedimentary environments [1] [2]. The conditions attending the formation of pyrites found in sediments or sedimentary rocks, and the factors limiting its formation have been inferred in several ways [3]. They allow sedimentary redox conditions to be identified as oxic, suboxic, anoxic or euxinic. Moreover, some studies particularly were interested to pyrites morphology in sedimentary rocks [4] [5]. The most widely accepted view is that euhedral and framboidal pyrite is regularly formed in sedimentary environments under anoxic conditions.

In Africa, studies on pyrite deposits in sediments or sedimentary basins are rare and particularly in the Gulf of Guinea basins, and notably in Cameroonian coastal basins. In this geological environment, pyritic formations with interesting concentration were only signalized in the Douala sub-basin of Cameroon [6]. However, no study has been carried out on their occurrences or morphology.

The aim of this study is to examine the geological, mineralogical and geochemical aspects of Pk27 pyritic deposits of Paleocene-Eocene N'Kapa Formation (Douala sub-basin, Cameroon) in order to characterize the mineralization for his industrial utilization. For this purpose, first of all, the geological description of pyritic formations was presented and later hand specimens taken from the pyrite-bearing rocks and their host rocks were analyzed physically and mineralogically and studied geochemically.

\section{Geographical and Geological Settings}

The study area is located at Pk27 in the north-eastern part of the Douala sub-basin (Cameroon, Central Africa) between latitude $4^{\circ} 10^{\prime}-4^{\circ} 12^{\prime} \mathrm{N}$ and longitude $9^{\circ} 50^{\prime}-9^{\circ} 53^{\prime} \mathrm{E}$ (Figure 1), within a humid equatorial climatic zone. The annual rainfall ranges between 3000 and $5000 \mathrm{~mm}$, and the annual average temperature is $26^{\circ} \mathrm{C}$ [7]. The vegetation is a dense rainforest transformed by the human activities [8]. The geomorphology of the study area is a coastal plain with low altitudes $(40-120 \mathrm{~m})$. This area shows hills with flat and sharp summits and it is deeply incised by $\mathrm{V}$ and $\mathrm{U}$ shape valleys. According to the geological report [9], the relative age of Pk27 pyrite deposits area is Paleocene-Eocene corresponding to the N'kapa Formation.

The lithostratigraphy of Douala sub-basin is constituted by seven major Formations related to its geodynamic and sedimentary evolution [11]. (1) The syn-rift period represented by the Mundeck Formation (Aptian-Cenomanian), which lies unconformably on the Precambrian basement and consists of continental and fluvio-deltaic deposits, i.e., clays, coarse-grained sandstones, conglomerates. The post-rift sequence includes: (2) the Logbadjeck Formation (Cenomanian-Campanian), lying unconformably on the Mundeck Formation and composed of micro-conglomerates, sand, sandstone, limestone, and clay; (3) the Logbaba Formation (Maastrichtian), mainly composed of sandstone, sand and fossiliferous clay; (4) the N'kapa Formation (Paleocene-Eocene), rich in marl and clay with lenses of sand and fine to coarse-grained unconsolidated sandstone; (5) the Souellaba Formation (Oligocene) lying unconformably on N'kapa deposits and characterized by marl deposits with some interstratified lenses of channel sands; (6) the Matanda Formation (Miocene), dominated by deltaic facies interstratified with volcano-clasties layers; (7) the Wouri Formation (Plio-Pleistocene) which consists of gravelly and sandy deposits with a clayey or kaolinitic matrix.

\section{Material and Methods}

The study was carried out on the Pk27 outcrops along the low slopes of valleys where the most representative 


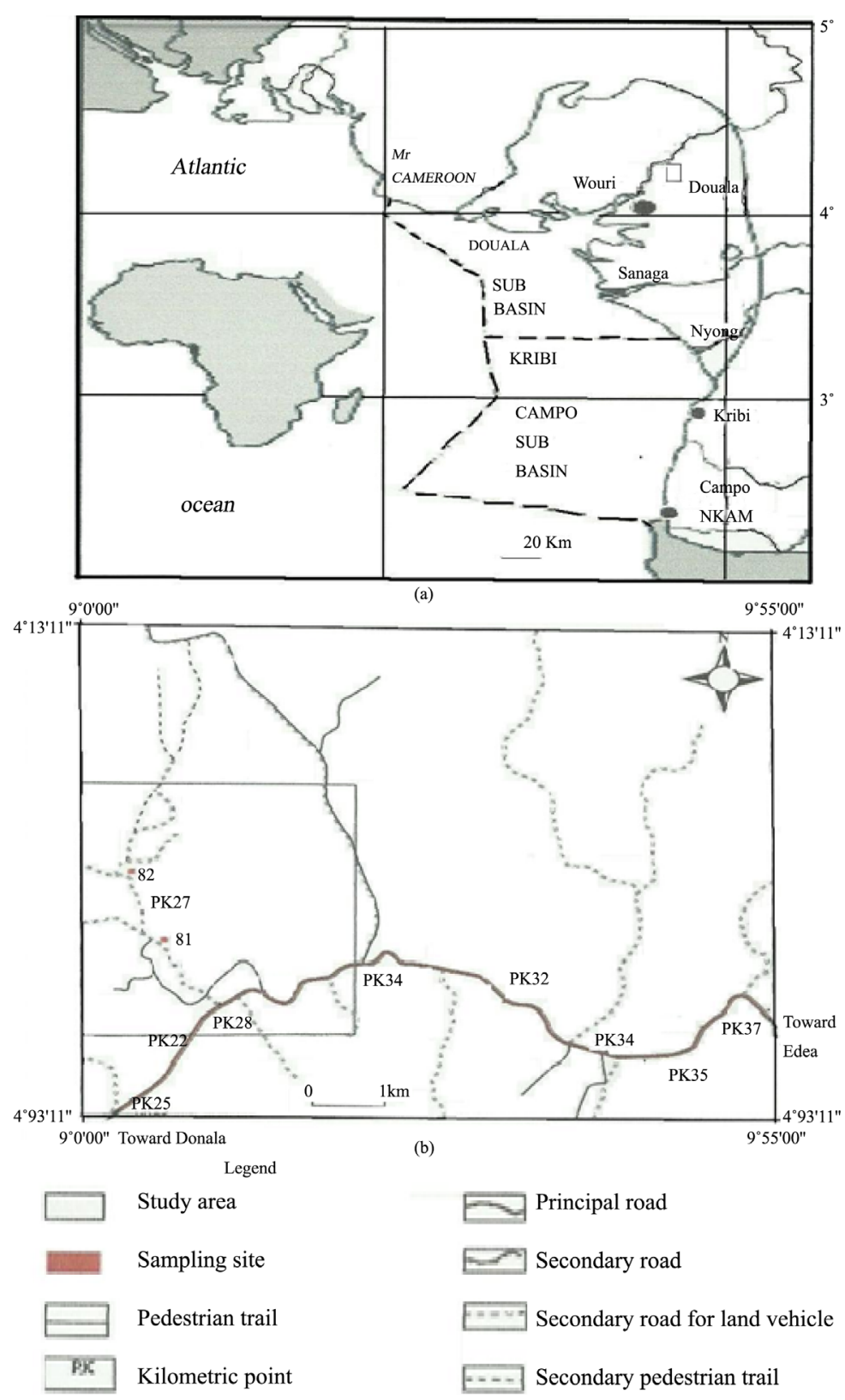

Figure 1. Sketch map of Douala and Kribi/Campo sub-basins [10] (a); Localization of the study area (b).

types of pyritic formations of the Douala sub-basin were observed. Two main sedimentary facies were observed in the area including claystones or silty-claystones and conglomerates with interstratified light lenses of sandstones. However, five lithofacies were described on the representative outcrops (site S1) and the pit (site S2) (Figures 2(a)-(d)) and classified [12] [13], and using the Munsell color chart. A total of four claystones samples which are the main lithofacies bearing pyrite and pyrite samples were collected on the field for analyses.

Various analyses were performed on the collected samples including particle size distribution with their parameters, mineralogical and chemical analyses.

The particle size measurement of clay samples and pyrite-bearing rocks was carried out in two steps: (i) a conventional sieving for the 50 to $2000 \mathrm{~mm}$ fractions where pyrite samples were sorted out; (ii) using a sedigraph 5000 in automatic procedure for clay and silt fractions. Particle size parameters including Quartiles (Q1, Q2 and Q3 correspond respectively to particle size of cumulated percent of 75\%, 50\% and 25\%), Sorting index 


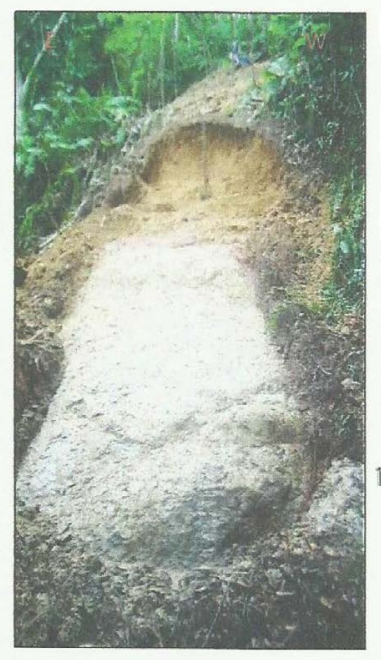

(a)

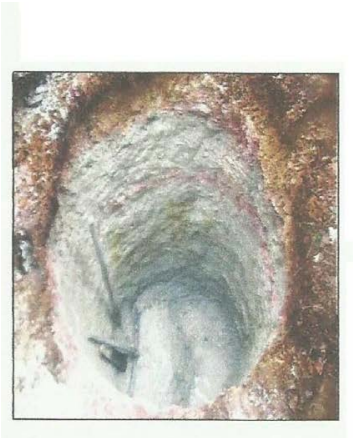

(c)

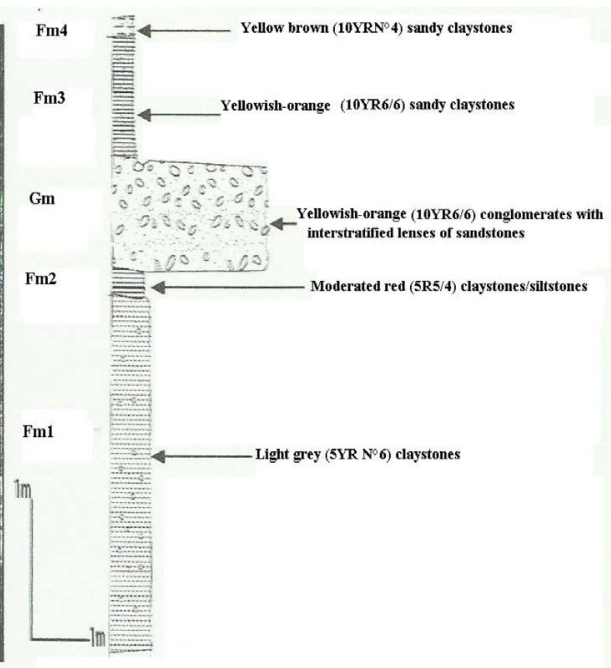

(b)

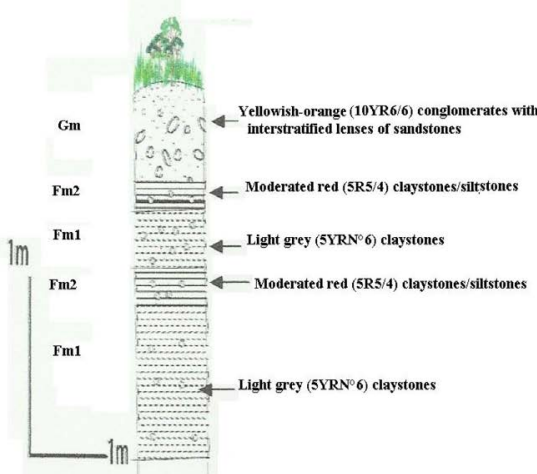

(d)

Figure 2. Picture (a) and $\log$ (b) of the outcrop of pK27 pyritic formation in site S1; picture (c) and profile (d) of the pit of pyritic formation in site S2.

(So) and Coefficient of Asymmetry (A) were determined using the Trask method [14] with:

$$
\begin{gathered}
S_{0}=\left(Q_{3} / Q_{1}\right)^{1 / 2} \\
A=Q_{1} \times\left(Q_{3} / Q_{2}\right)^{2}
\end{gathered}
$$

Mineralogical surveys were carried out using optical microscope on sand fractions and X-ray diffraction. Optical studies were carried under polarized light and analyzed light on sand fractions obtained after paned the clayey materials in order to determine the mineralogy of heavy minerals [15]. X-ray diffractions were performed on bulk samples of four representative claystones samples using a Brünker diffractometer D8 ADVANCE with a copper source $(\lambda=1.5489 \AA)$ working under $40 \mathrm{kV}$ and $40 \mathrm{~mA}$. The exposure time for qualitative analysis was 2 h. Samples were pulverized with an agate mortar; the resulting powder was picked up on a piece of tape before being irradiated with $\mathrm{CuK} \alpha$ radiation in the diffractometer.

The chemical investigations were carried out by X-ray fluorescence spectrometry (XRF) on a Siemens SRS 3000 apparatus. The samples were analyzed for major and trace elements. Powdered samples were heated to $110^{\circ} \mathrm{C}$ for $6 \mathrm{~h}$, followed by heating in a muffle furnace at $1000^{\circ} \mathrm{C}$ for $2 \mathrm{~h}$ to determine LOI (loss on ignition). Lithium tetra-borate was mixed with the powdered samples and heated to $1000^{\circ} \mathrm{C}$ to form a fused sample for X-ray fluorescence analysis. Final analyses were carried out using a Rigaku model RIX-3000 equipped with an $\mathrm{Rh}$ tube. Resulting chemical analyses for major and trace elements have detection limit of $1 \mathrm{ppm}$. 


\section{Results}

\subsection{Facies Analysis}

The outcrops (site S1) and the pit (site S2) from Pk27 show two main types of sedimentary facies. From the bottom to the top, one can distinguish: claystones and conglomerates with interstratified sandstones (Figures 2(a)-(d)). These sediments contain cobbles to fine-grained quartz, kyanite, grenat, rutile which suggest their terrestrial source. In general, conglomerates vary from yellow to yellowish brown color and claystones show light grey, yellowish-orange and red color. These sedimentary materials from the study area were grouped into five (05) main lithofacies including: four claystone facies and one conglomeratic facies. Facies have been described, interpreted and classified from coarsest $(\mathrm{G})$ to finest $(\mathrm{F})$ sediments and a code (Table 1) modified [12] [13] has been assigned to each facies.

\subsubsection{Claystone Facies}

Four major claystone facies were observed on the field below and above the conglomeratic facies and were described (Table 1). They are massive, silteous, pyriteous or not and contain a light or weakly sand fraction. From the bottom to the top, one can distinguish (Figures 2(a)-(d)):

Facies Fm1: massive claystones. Massive and compact light grey (5YR N ${ }^{\circ}$ ) claystones have silty-clayey and sandy texture with yellow and red spots. The thickness of this facies varies from 80 to $200 \mathrm{~cm}$. This facies contains fine sand fraction of quartz and centimetric to decimetric crumbly and consolidated piles with aggregates pyrites disseminated in clay mass with oolithic concretions, globular, cubic, octaedric, massive and fossiliferous pyrite forms (Figures 3(a)-(e)). The top boundary with Fm2 is sharp. The Fm1 facies has the highest pyrite contain and is the main pyritic formation of the area.

Facies Fm2: claystones/siltstones. This red (5R 5/4) facies is massive, thin-laminated and have silty-clayey and sandy texture with yellow, white and grey spots. The thickness of this facies varies from 10 to $20 \mathrm{~cm}$. The Fm2 facies contains fine sand fraction of quartz and centimetric to decimetric crumbly piles with aggregates pyrites less abundant than the Fm1 facies. These aggregates pyrites are disseminated in the clay mass. The top boundary with conglomeratic facies $(\mathrm{Gm})$ is sharp.

Facies Fm3: massive claystones. The Fm3 facies is massive and has yellowish-orange color (10YR 6/6) and sandy-clayey texture. The thickness of this facies varies from 80 to $110 \mathrm{~cm}$. This facies contains fine and coarsegrained quartz. Pyrite is absent in this facies. The basal and top boundaries are sharp.

Facies Fm4: massive claystones. The Fm4 facies is massive and have yellowish-brown color (10YR $\left.\mathrm{N}^{\circ} 4\right)$ and sandy-clayey texture. The thickness of this facies varies from 10 to $15 \mathrm{~cm}$. It contains fine and coarse-grained quartz and abundant organic matter. Pyrite is absent in this facies. The basal boundary with Fm3 facies is sharp.

Table 1. Facies description of the pK27 pyrite deposit classification [12] [13].

\begin{tabular}{|c|c|c|c|}
\hline Facies code & Lithology & Sedimentary structures & $\begin{array}{c}\text { Depositional process and } \\
\text { interpretation }\end{array}$ \\
\hline $\mathrm{Gm}$ & $\begin{array}{l}\text { Matrix supported cobble to conglomerate rounded } \\
\text { to sub rounded; fine-to medium sand coarse may be } \\
\text { pebble; poorly sorted. }\end{array}$ & Massive ferruginous lamination. & Cohesive debris flow [13]. \\
\hline Fm1 & $\begin{array}{l}\left.\text { Claystone (light grey, } 5 \mathrm{YRN}^{\circ} 6\right) \text {, silteous, } \\
\text { pyriteous, fine-grained sandstone } \\
(<2 \mathrm{~mm}) \text {, poorly sorted. }\end{array}$ & Mould of pyritic gastropod & $\begin{array}{c}\text { Low energy; deposition from } \\
\text { suspension or from weak traction } \\
\text { current [12]. }\end{array}$ \\
\hline Fm2 & $\begin{array}{l}\text { Claystone/siltstones with layers of silt } \\
\text { (moderated red color, } 5 \mathrm{R} 5 / 4) \text {; fine grained of } \\
\text { sandstone }(<2 \mathrm{~mm}) \text {; micaceous, } \\
\text { crumbly piles to aggregates pyrite. }\end{array}$ & Fine horizontal laminated & $\begin{array}{l}\text { Low energy; deposition from } \\
\text { suspension or from weak traction } \\
\text { current }[12] .\end{array}$ \\
\hline Fm3 & $\begin{array}{l}\text { Claystones with layers of silt (yellowish-orange } \\
\text { color, 10YRN } 4) \text { fine grained of sandstone } \\
(<2 \mathrm{~mm}) \text { without pyrite. }\end{array}$ & Fine horizontal laminated & $\begin{array}{l}\text { Low energy; deposition from } \\
\text { suspension or from weak traction } \\
\text { current }[12] .\end{array}$ \\
\hline Fm4 & $\begin{array}{l}\text { Claystones (yellow brown color, 10YR6/6); } \\
\text { organic matter fine grained of sandstone } \\
(<2 \mathrm{~mm}) \text { without pyrite. }\end{array}$ & Bioturbation & $\begin{array}{l}\text { Low energy; deposition from } \\
\text { suspension or from weak traction } \\
\text { current [12]. }\end{array}$ \\
\hline
\end{tabular}



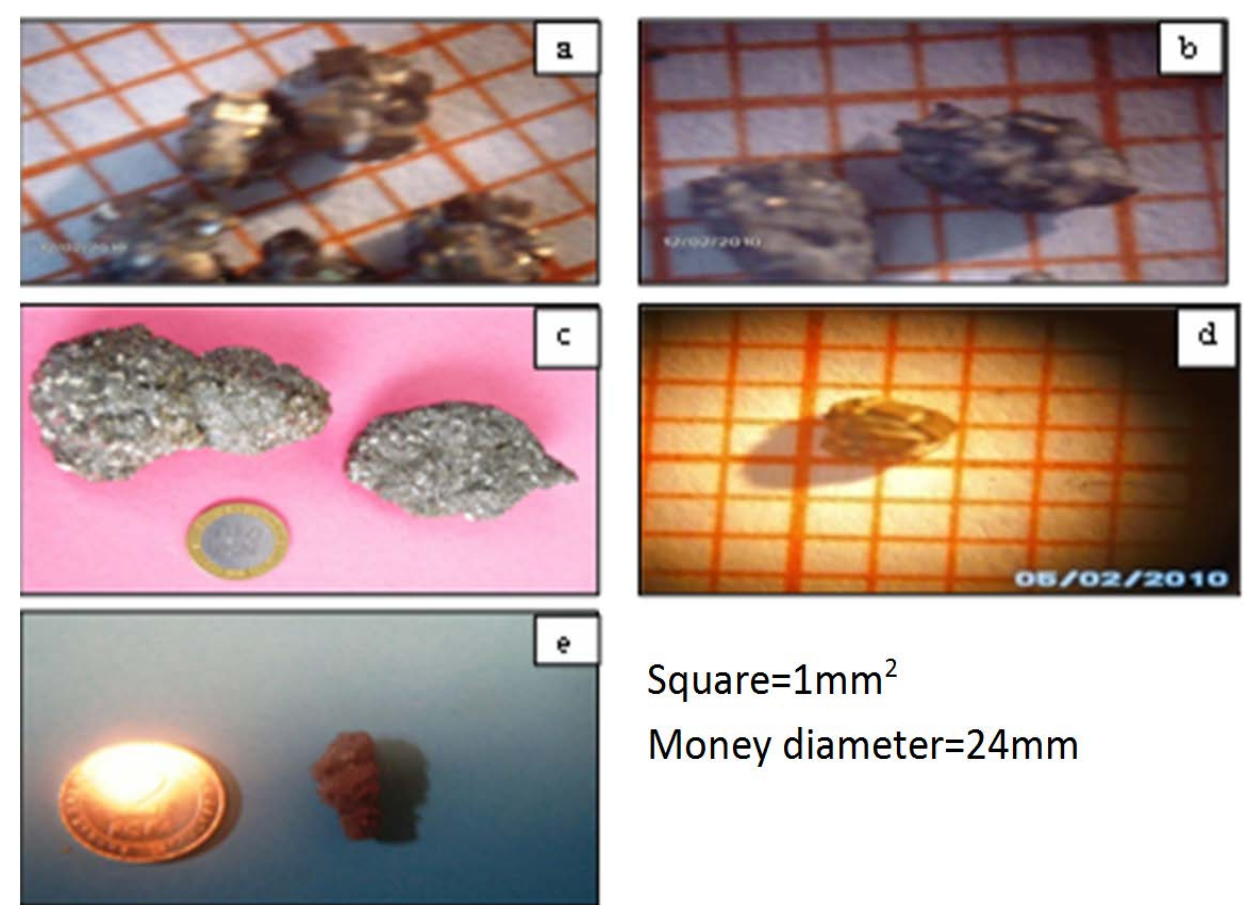

\section{Square $=1 \mathrm{~mm}^{2}$ \\ Money diameter $=24 \mathrm{~mm}$}

Figure 3. Morphology of piles and aggregates pyrite in pK27 deposit. (a) cubic and octaedric pyrite; (b) sub-rounded pyrite; (c) massive and angular pyrite; (d) oolithic or concretionary pyrite; (e) mould of pyritic gastropod (fossiliferous form).

\subsubsection{Conglomerates Facies}

One facies of massive conglomerates is described in Table 1. This facies contains subangular to rounded pebbles and boulders of variable size and nature (quartz, clayey clasts).

Facies Gm: massive conglomerates. These conglomerates are characterized by yellowish-orange color (10YR 6/6) with interstratified thin lenses of sandstones. They have subangular to rounded clasts with variable size from granules to cobbles of quartz and iron duricrusts. The sandy matrix content is about $20 \%-30 \%$ of the total. The basal and top boundaries with Fm2 and Fm3 are sharp.

\section{Particle Size Distribution and Their Parameters}

The particle size distribution of clayey materials bearing pyrites is given according to the USDA classification system (gravel: $2<\mathrm{d}<75 \mathrm{~mm}$; sand: $50 \mu \mathrm{m}<\mathrm{d}<2 \mathrm{~mm}$; silt: $2 \mu \mathrm{m}<\mathrm{d}<50 \mu \mathrm{m}$; clay: $\mathrm{d}<2 \mu \mathrm{m}$ ). These materials have a small amount of sand $(5.5 \%-12.5 \%)$ and gravel $(1 \%-2 \%)$, and are essentially constituted of clays $(51 \%-56 \%)$ and silts $(27 \%-49 \%)$. Figure 4 shows similar patterns which indicate that these clayey materials have the same constituents with a rapid increase towards clays and silts fractions.

However, to analyze the sorting of these clayey materials and to determine the hydrodynamic conditions of their deposit, values of particle size parameters including: Quartiles $\left(\mathrm{Q}_{1}, \mathrm{Q}_{2}, \mathrm{Q}_{3}\right)$, Sorting index (So) and Coefficient of asymmetry (A) are showed on Table 2. The clayey materials bearing pyrite have the sorting index (So) higher than 4.5 and the coefficient of asymmetry (A) higher than 1 whose indicate respectively that these materials are poorly sorted and are the torrential type; whereas the sorting is orientated towards fine particles.

Figure 5(a) and Figure 5(b) represent the particle size distribution of pyrite in the sand fractions with diameter $\mathrm{d}>80 \mu \mathrm{m}$. These histograms show that the grains, piles and aggregates pyrite are concentrated between 0.4 to $8 \mathrm{~mm}$ diameters with essentially a unimodal distribution for samples S1T1c, S1T1b, S2P2a and S2P2b or exceptionally a bimodal distribution centered in $4 \mathrm{~mm}$ and $0.1 \mathrm{~mm}$ diameters in S1T1a sample. In fact, the coarse pyrite of clayey materials is dominantly constituted with sand and gravel size.

\section{Mineralogical and Geochemical Characterization}

X-ray diffraction patterns indicate that clayey materials of PK27 area (Figure 6) are essentially kaolinitic and il- 


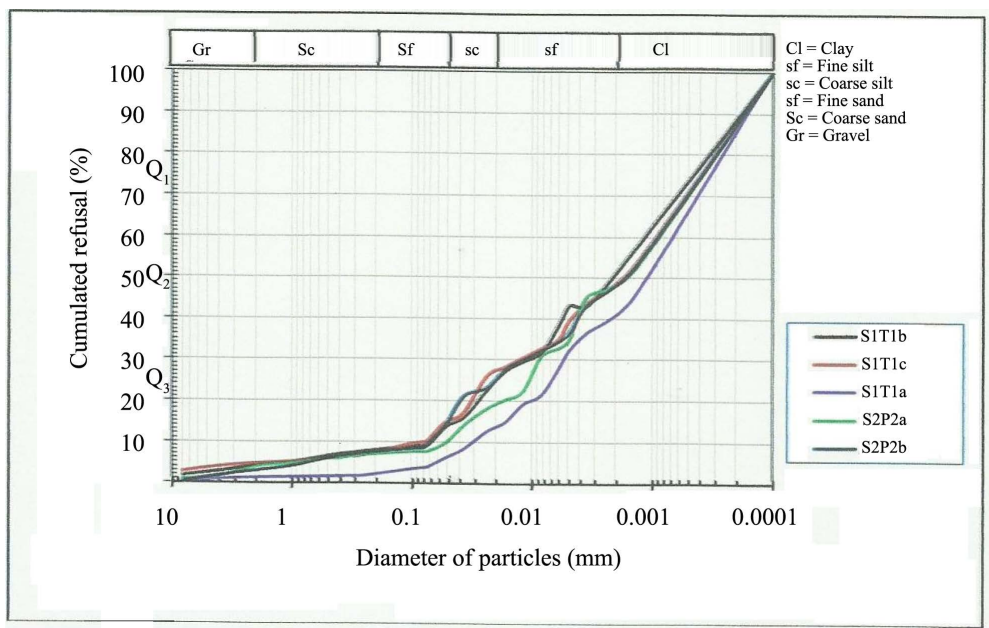

Figure 4. Cumulative curves of particles size distribution of samples S1T1a, S1T1b and S1T1c of site S1, and samples S2P2a and S2P2b of site S2 of pyrite deposit of $\mathrm{pK} 27$.
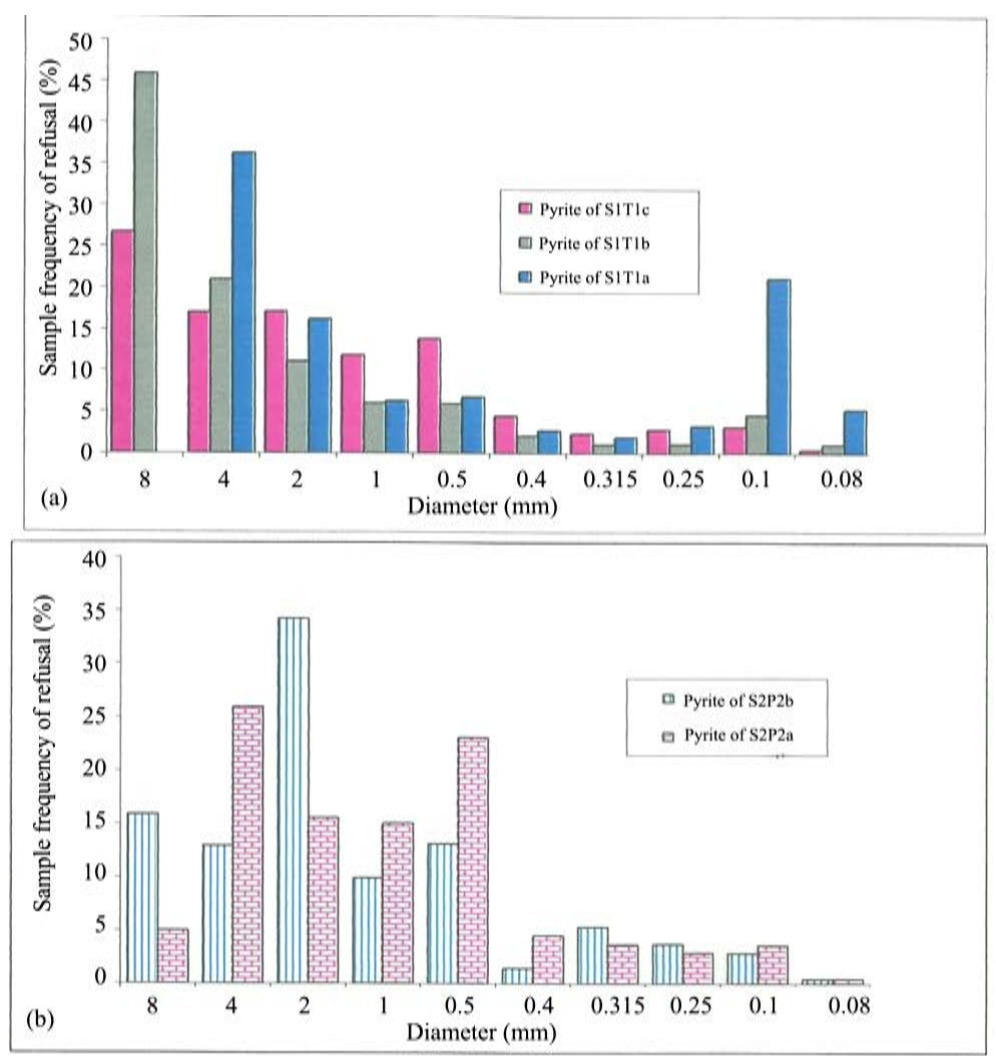

Figure 5. Histograms of particles size distribution of coarse pyrite $(>80 \mu \mathrm{m})$ in samples S1T1a, S1T1b and S1T1c of site S1 (a) and S2P2a and S2P2b of site S2 (b).

litic, followed by goethite, quartz, pyrite, halloysite and anatase. Rutile and hematite are accessory minerals. Furthermore, optical observations of heavy minerals of sand fractions show that in these sedimentary clayey materials, pyrite is accompanied by kyanite, grenat, rutile, diopside and tourmaline (Figure 7). These minerals are recognized as minerals of regional metamorphism.

Major elements of the studied samples (Table 3) show the following composition: silica $(60.3 \%-64.1 \%$ 


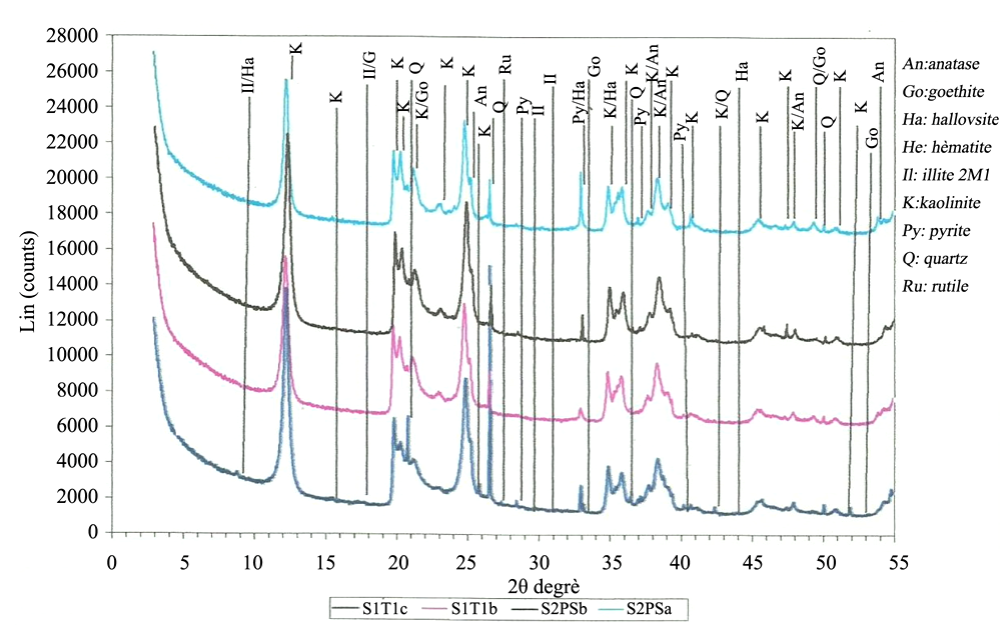

Figure 6. X-ray patterns of clayey materials of pK27 pyritic deposit.
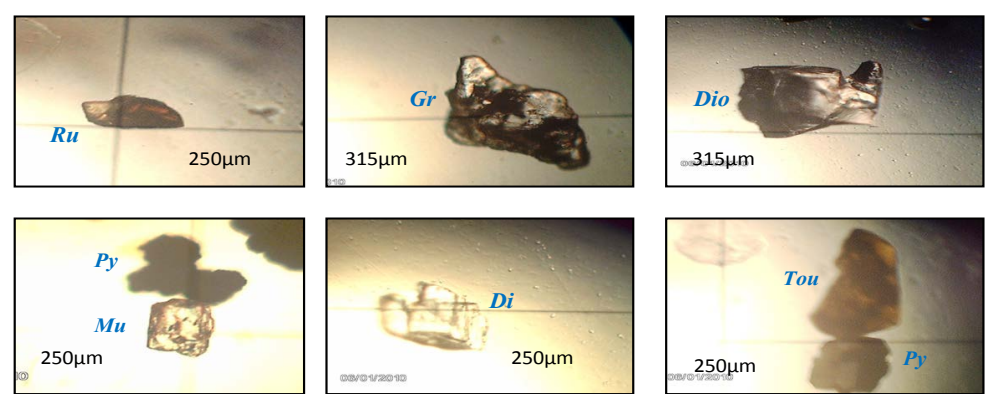

Figure 7. Mineralogy of coarse fractions in polarized light (PL) of analyzed clayey materials of pK27 pyrite deposit. Ru: rutile; Gr: grenat; Dio: diopside; Mu: muscovite; Py: pyrite; Di: kyanite; Tou: tourmaline.

Table 2. Particle size parameters of clayey materials bearing pyrite of pK27 pyrite deposit.

\begin{tabular}{cccccccc}
\hline Site & Samples & Depht $(\mathrm{cm})$ & \multicolumn{3}{c}{ Particle size parameters } \\
\hline & & & $\mathrm{Q}_{1}(\mathrm{~mm})$ & $\mathrm{Q}_{2}(\mathrm{~mm})$ & $\mathrm{Q}_{3}(\mathrm{~mm})$ & So & $\mathrm{A}$ \\
\hline \multirow{2}{*}{$\mathrm{S} 1$} & S1T1a & $150-200$ & 0.0003 & 0.001 & 0.0065 & 4.65 & 1.95 \\
& S1T1b & $250-300$ & 0.0004 & 0.0015 & 0.025 & 7.91 & 4.44 \\
& S1T1c & $350-400$ & 0.00046 & 0.001 & 0.02 & 6.59 & 8 \\
S2 & S2P2a & $65-105$ & 0.0004 & 0.0015 & 0.01 & 5 & 1.78 \\
& S2P2b & $120-200$ & 0.0004 & 0.00125 & 0.02 & 7.07 & 5.12 \\
\hline
\end{tabular}

$\left.\mathrm{SiO}_{2}\right)$, alumina $\left(12.6 \%-16.7 \% \mathrm{Al}_{2} \mathrm{O}_{3}\right)$ and iron $\left(2.28 \%-4.1 \% \mathrm{Fe}_{2} \mathrm{O}_{3}\right)$. Iron contents are variable in the clayey materials in relation with the color $\left(2.28 \% \mathrm{Fe}_{2} \mathrm{O}_{3}\right.$ for light grey clays, $4.1 \% \mathrm{Fe}_{2} \mathrm{O}_{3}$ for light grey with red spots). Indeed, this variation characterizes the clayey materials of the eastern part of the Douala sub-basin [16]. The sum of bases $\left(\mathrm{CaO}, \mathrm{Na}_{2} \mathrm{O}, \mathrm{K}_{2} \mathrm{O}, \mathrm{MgO}\right)$ is low, less than $1 \%$. The $\mathrm{SO}_{3}$ content varies between 2.15 and $4.03 \%$; whereas it's abundant $(50.86 \%-57.64 \%)$ in pyrite minerals and is followed by $\mathrm{Fe}_{2} \mathrm{O}_{3}$ content $(20.29 \%$ 24.34\%).

Trace element concentrations of pK27 analyzed samples are respectively reported in Table 3. This table shows the same behavior with trace elements in clayey materials and pyrite. These materials are systematically depleted in Large Ion Lithophile Element (LILE) like $\mathrm{Sr}(<51 \mathrm{ppm})$, High Field Strength Elements (HFSE) like $\mathrm{Nb}(<40 \mathrm{ppm})$ and $\mathrm{Zr}(<200 \mathrm{ppm}$ in general with the exception of sample S1T1b). However, they are enriched in TTE or Transition Trace Elements like Cr, V, and Ni (in site S2), with exception of Co in S2P2b sample. 
Table 3. Major and trace element compositions of analyzed clayey materials and pyrites of pK27 pyrite deposit.

\begin{tabular}{|c|c|c|c|c|c|c|c|c|c|}
\hline & \multirow{2}{*}{$\begin{array}{c}\text { Type } \\
\text { Samples }\end{array}$} & \multicolumn{5}{|c|}{ Clay with pyrite } & \multicolumn{3}{|c|}{ Pyrite } \\
\hline & & $\mathrm{S} 2 \mathrm{P} 2 \mathrm{a}$ & $\mathrm{S} 2 \mathrm{P} 2 \mathrm{~b}$ & $\mathrm{~S} 1 \mathrm{~T} 1 \mathrm{~b}$ & S1T1c & $\mathrm{S} 2 \mathrm{P} 2 \mathrm{a}$ & $\mathrm{S} 2 \mathrm{P} 2 \mathrm{~b}$ & S1T1b & S1T1c \\
\hline & Depth (cm) & $65-105$ & $120-200$ & $250-300$ & $350-400$ & $65-105$ & $120-200$ & $250-300$ & $350-400$ \\
\hline \multicolumn{10}{|c|}{ Major elements (W\%) } \\
\hline & DL & & & & & & & & \\
\hline $\mathrm{SiO}_{2}$ & 0.0001 & 62.3 & 61.2 & 65.13 & 64.1 & 6.78 & 4.6 & 10.02 & 11.6 \\
\hline $\mathrm{Al}_{2} \mathrm{O}_{3}$ & 0.0001 & 14.8 & 16.7 & 11.9 & 12.6 & 4.89 & 4.69 & 8.23 & 7.43 \\
\hline $\mathrm{CaO}$ & 0.0001 & 0.056 & 0.056 & 0.06 & 0.062 & 0.12 & 0.216 & 0.069 & 0.078 \\
\hline $\mathrm{Fe}_{2} \mathrm{O}_{3}$ & 0.0001 & 2.56 & 2.281 & 4.068 & 4.098 & 22.44 & 24.34 & 21.36 & 20.29 \\
\hline $\mathrm{K}_{2} \mathrm{O}$ & 0.0001 & 0.182 & 0.172 & 0.023 & 0.027 & 0.17 & 0.158 & 0.042 & 0.045 \\
\hline $\mathrm{MgO}$ & 0.0001 & 0.02 & - & - & - & - & - & - & - \\
\hline $\mathrm{MnO}$ & 0.0001 & - & - & - & - & - & - & - & - \\
\hline $\mathrm{Na}_{2} \mathrm{O}$ & 0.0001 & - & - & - & - & - & - & - & - \\
\hline $\mathrm{SO}_{3}$ & 0.0001 & 2.43 & 2.15 & 4.01 & 4.03 & 55.64 & 57.64 & 52.06 & 50.86 \\
\hline $\mathrm{P}_{2} \mathrm{O}_{5}$ & 0.0001 & 0.36 & 0.27 & 0.16 & 0.25 & 0.23 & 0.28 & 0.24 & 0.24 \\
\hline $\mathrm{TiO}_{2}$ & 0.0001 & 1.534 & 1.526 & 1.57 & 1.691 & 0.36 & 0.438 & 0.5 & 0.7 \\
\hline LOI & & 15.62 & 15.58 & 12.34 & 13.02 & 8.38 & 7.38 & 7.01 & 8.72 \\
\hline Total & & 99.86 & 99.95 & 99.26 & 99.93 & 99.01 & 99.79 & 99.53 & 99.279 \\
\hline \multicolumn{10}{|c|}{ Trace elements in ppm } \\
\hline Co & 0.0001 & - & - & - & - & 389 & 474 & 48 & - \\
\hline $\mathrm{Cu}$ & 0.0001 & 70 & 50 & 61 & 61 & 180 & 140 & - & - \\
\hline $\mathrm{Cr}$ & 0.0001 & 200 & 195 & 160 & 160 & 130 & 170 & 120 & 120 \\
\hline $\mathrm{Ga}$ & 0.0001 & 43 & 52 & - & - & - & - & - & - \\
\hline $\mathrm{Nb}$ & 0.0001 & - & - & 37 & 37 & - & - & - & - \\
\hline $\mathrm{Ni}$ & 0.0001 & 65 & 60 & 80 & 60 & 1542 & 1800 & 60 & - \\
\hline $\mathrm{Sr}$ & 0.0001 & 50 & 50 & - & - & - & - & - & - \\
\hline V & 0.0001 & 317 & 377 & 294 & 294 & - & - & 110 & 90 \\
\hline $\mathrm{Zn}$ & 0.0001 & 30 & 40 & - & - & - & - & - & - \\
\hline $\mathrm{Zr}$ & 0.0001 & 180 & 160 & 560 & 560 & 30 & - & 170 & 150 \\
\hline $\mathrm{Co}: \mathrm{Ni}$ & & & & & & 0.25 & 0.26 & 0.8 & \\
\hline
\end{tabular}

\section{Discussion}

\subsection{Depositional Settings}

Two main types of sedimentary facies characterize the pyrite deposit of pK27: from the bottom to the top one can distinguish claystones and conglomerates with interstratified sandstones. Based on the facies analysis and sequences described above, the sedimentological character of the outcrops and the presence of abundant detrital material are indicative of alluvial fan-fan delta deposits. In fact, conglomerates (Gm facies) show no internal structure and result from high strength debris and gravity flows [13]; whereas claystones (Fm facies) result from 
suspension in calm environment or from weak traction currents [12].

The clayey materials bearing pyrite are essentially constituted. Moreover, to analyze the sorting of these clayey materials and to determine the hydrodynamic conditions of their deposit, some parameters such as sorting index (So) and coefficient of asymmetry were determined. In fact, Trask [14] shows that if So $<2.5$, sediments are well sorted and correspond to marine sediments (beach) or fluvial sediments; if $2.5<$ So $<3.5$, sediments are normally sorted and the hydrodynamic conditions are difficult to determine; if $3.5<$ So $<4.5$, sediments are much sorted; and if So $>4.5$, sediments are poorly sorted and are the torrential type. Moreover, the coefficient of asymmetry (A) also shows the sorting of sediments and the hydrodynamic conditions of their deposits; if $\mathrm{A}<1$, the sorting is orientated towards coarse particles and grains are more sorted. In this case, they are torrential deposits; whereas $\mathrm{A}=1$ indicates developed sediments and $\mathrm{A}>1$ a maximum sorting towards fine particles and corresponds to marine deposits. In general, all the analyzed clayey samples of Pk27 show that the sorting index (So) is higher than 4.5 and corresponds to poorly sorted sediments whereas their coefficient of asymmetry (A) higher than 1 indicates that the sorting is carried out towards fine particles (clays and silts).

\subsection{Ore Genesis}

The geological survey of pK27 area shows pyrite in clayey materials. Pyrite in sedimentary rocks has been also found in shale and marl in the world [1] [2] and in the others members of the N'Kapa Formation at Dizangue [17] and in the northern part of the Douala sub-basin at the Kompina pyrite deposit [6]. The mineralogical compositions of the host rocks are essentially constituted with kaolinite and illite, followed by goethite, quartz, pyrite, halloysite, anatase, hematite and rutile. All these minerals have been recognized as weathering products of the rocks schist around the coastal plain in the littoral part of Cameroon, and are the main characteristic of Paleocene-Eocene and Miocene-Pliocene clay sediments of Missole II and Bomkoul areas in the Douala sub-basin [16]. Also, the presence of kyanite, grenat, rutile, diopside, muscovite and tourmaline in these materials are indicative of regional metamorphism of the rocks source. However, high $\mathrm{SO}_{3}$ content and trace elements contents like $\mathrm{Ni}, \mathrm{Co}, \mathrm{Cu}, \mathrm{Zn}$ of clayey sediments of Pk27 area particularly characterize these sediments in the eastern part of the Douala sub-basin. These various trace elements may be concentrated in pyrites of different origin [18]. The concentration of metals in pyrite depends on the concentrations of the various metals in the precipitation environment. Metals that may circulate in a hydrologic column become fixed in sediments rich in organic material [19].

In fact, many elements, such as $\mathrm{Cu}, \mathrm{Zn}, \mathrm{As}, \mathrm{Sb}, \mathrm{Ni}$ and $\mathrm{Co}$, may be highly concentrated in sedimentary rocks, especially in anoxic sediments [20]. These elements may aid in elucidation of ore genesis [21]. For example, the $\mathrm{Co}$ and Ni contents of pyrites or their Co:Ni ratios, are primarily used as indicators of ore genesis [22]. The Co and $\mathrm{Ni}$ contents are extremely variable in hydrothermal pyrites and rather variable Co:Ni ratios. Pyrites in massive sulphide deposits have Co:Ni ratios of 5 - 50 (average 8.7), with high Co contents (average $480 \mathrm{ppm}$ ) and Ni contents less than $100 \mathrm{ppm}$ (average $56 \mathrm{ppm}$ ) [22]. Sedimentary pyrites in shale have high Ni contents and low Co:Ni ratios (average 0.63 ) [22]. The Co contents of the studied clayey materials are in trace and are low in pyrites, but the Ni contents are high. The Co:Ni ratios of pyrites are approximately 0.25 to 0.8 . These values are characteristic of sedimentary pyrites and also suggest an anoxic environment [19]-[22]. Both elements Co and $\mathrm{Ni}$ with another TTE such as $\mathrm{Zn}$ and $\mathrm{Cu}$ tend to be enriched in sulphide minerals [23]. In the sedimentary environment, $\mathrm{Co}$ and $\mathrm{Ni}$ are enriched in pyrite and marcasite [3]. The mineralogical data of pk27 show pyrite minerals. However, high $\mathrm{Ni}$ contents in some pyrite samples should also indicate the presence of the nickeliferous form of pyrite (bravoite). But the major oxides in pyrites, such as $\mathrm{SiO}_{2}, \mathrm{Al}_{2} \mathrm{O}_{3}, \mathrm{CaO}, \mathrm{Na}_{2} \mathrm{O}, \mathrm{K}_{2} \mathrm{O}$ and $\mathrm{MgO}$ may have been derived from the clayey materials.

\section{Conclusions}

The sedimentary materials from the pyrite deposit of pK27 (Douala, sub-basin) were grouped into five (05) main lithofacies, including four claystone facies and one conglomeratic facies. Pyrite is concentrated in claystone facies precisely in massive and compact light grey claystones situated on the bottom of outcrops where it's present in different forms: centimetric to decimetric crumbly and consolidated grains, piles and aggregates pyrites with framboidal or oolithic concretions, euhedral or globular, cubic, octaedric and massive forms, and fossiliferous forms.

The particle size distribution of clayey materials bearing pyrite shows that they are essentially constituted of 
clay and silts fractions; whereas their Sorting index (So) higher than 4.5 corresponds to poorly sorted sediments and torrential type, and their Coefficient of asymmetry (A) higher than 1 indicates that the sorting is carried out towards fine particles (clays and silts).

The specific mineralogical composition of these clayey materials bearing pyrite indicates that they are essentially kaolinitic and illitic in which pyrite is associated with kyanite, grenat, rutile, diopside, and tourmaline, the minerals of regional metamorphism.

The specific chemical signature of $\mathrm{SO}_{3}$ content varies between $2.15 \%$ and $4.03 \%$ in clayey materials; whereas it's abundant $(50.86 \%-57.64 \%)$ in pyrite and is followed by $\mathrm{Fe}_{2} \mathrm{O}_{3}$ content $(20.29 \%-24.34 \%)$. The Co contents of the studied clayey materials are in trace and are low in pyrites, but the Ni contents are high. The $\mathrm{Co}$ :Ni ratios of pyrites are approximately 0.25 to 0.8 , are characteristic of sedimentary pyrites and also suggest an anoxic environment.

\section{Acknowledgements}

The authors are grateful to the staff of the "Laboratory of Mineral Chemistry" and GEMH of ENSCI, University of Limoges, France, for mineralogical and chemical analyses.

\section{References}

[1] Berner, R.A. (1984) Sedimentary Pyrite Formation: An Update. Geochimica et Cosmochimica Acta, 48, 605-615. http://dx.doi.org/10.1016/0016-7037(84)90089-9

[2] Calvert, S.E., Thode, H.G., Yeung, D. and Karlin, R.E. (1996) A Stable Isotope Study of Pyrite Formation in the Late Pleistocene and Holocene Sediments of the Black Sea. Geochimica et Cosmochimica Acta, 60, 1261-1270. http://dx.doi.org/10.1016/0016-7037(96)00020-8

[3] Álvarez-Iglesias, P. and Rubio, B. (2012) Early Diagenesis of Organic-Matter-Rich Sediments in a ría Environment: Organic Matter Sources, Pyrites Morphology and Limitation of Pyritization at Depth. Estuarine, Coastal and Shelf Science, 100, 113-123. http://dx.doi.org/10.1016/j.ecss.2012.01.005

[4] Taylor, K.G. and Macquaker, J.H.S. (2000) Early Diagenetic Pyrite Morphology in a Mudstone Dominated Succession: the Lower Jurassic Cleveland Ironstone Formation, Eastern England. Sedimentary Geology, 131, 77-86. http://dx.doi.org/10.1016/S0037-0738(00)00002-6

[5] Bölücek, C. and Ilhan, B. (2006) A Survey of Pyritised Animal, Plant, and Trace Fossils and Concretionary Pyrites, Germav Formation, Southeastern Turkey. Comptes Rendus Geoscience, 338, 161-171. http://dx.doi.org/10.1016/i.crte.2005.10.005

[6] Laplaine, J. (1969) Indices minéraux et ressources minérales du Cameroun. Bulletin de la Direction des Mines et Géologie, RFC, 113-115.

[7] Olivry, J.C. (1986) Fleuves et rivières du Cameroun. Meres, ORSTOM, Paris, 733 p.

[8] Letouzey, R. (1985) Etude phytogéographique du Cameroun. Ed. P Le chevalier, Paris, 508 p.

[9] SNH/UD (2005) Stratigraphie séquentielle et tectonique des dépôts mésozo syn-rifts du Bassin de Kribi/Campo. Auteurs: Ntamak-Nida, M.J., Mpesse, J.E., Ketchemen-Tandia, B., Ndong Ondo, S., Courville, P. and Baudin, F., Rapport Interne, $134 \mathrm{p}, 11$ planches, 02 rapports annexes d'analyses.

[10] Ntamak-Nida, M.J., Baudin, F., Schnyder, J., Makong, J.C., Komguem, P.B. and Abolo, G.M. (2008) Depositional Environments and Characterization of the Organic Matter of the Lower Mundeck Formation (Barremian ?-Aptian) of the Kribi-Campo Sub-Basin (South Cameroon): Implications for Petroleum Exploration. Journal of African Earth Sciences, 51, 207-230. http://dx.doi.org/10.1016/j.jafrearsci.2008.01.006

[11] Regnoult, J.M. (1986) Synthèse géologique du Cameroun. D.M.G., Yaoundé, 118p.

[12] Miall, A.D. (1978) Lithofacies Types and Vertical Profile Models in Braided River Deposits: A Summary. In: Miall, A.D., Ed., Fluvial Sedimentology, Vol. 5, Canadian Society of Petroleum Geologists, Calgary, 859.

[13] Postma, G. (1990) Depositional Architecture and Facies of River and Fan Deltas: A Synthesis. In: Colella, A., Prior, D.B., Eds., Coarse-Grained Deltas, Vol. 10, Blackwell Publishing Ltd., Oxford, 13-28. http://dx.doi.org/10.1002/9781444303858.ch2

[14] Berthois, L. (1975) Les roches sédimentaires: Etude sédimentologique des roches meubles. Doin, Paris, 279 p.

[15] Parfenoff, A., Pomerol, C. and Tourenq, J. (1970) Les minéraux en grains: Méthodes d'études et détermination. Masson et Cie, Paris, 578 p.

[16] Ngon Ngon, G.F., Mbog, M.B., Etame, J., Ntamak-Nida, M.J., Logmo, E.O., Gérard, M., Yongue-Fouateu, R. and Bi- 
long, P. (2014) Geochemistry of the Paleocene-Eocene and Miocene-Pliocene Clayey Materials of the Eastern Part of the Wouri River (Douala Sub-Basin, Cameroon): Influence of Parent Rocks. Journal of African Earth Sciences, 91, 110-124. http://dx.doi.org/10.1016/j.jafrearsci.2013.12.005

[17] Njike Ngaha, P.R. (2004) Palynostratigraphie et Reconstitution des Paléoenvironnements du Crétacé de l'Est du bassin Sédimentaire de Douala (Cameroun). Thèse de doctorat d'Etat, Université de Yaoundé I, Yaounde, 258 p.

[18] Craig, J.R., Vokes, F.M. and Solberg, T.N. (1998) Pyrite: Physical and Chemical Textures. Mineral Deposita, 34, 82102. http://dx.doi.org/10.1007/s001260050187

[19] Vine, J.D. and Tourtelot, E.B. (1970) Geochemistry of Black Shale Deposits: A Summary Report. Economic Geology, 65, 253-272. http://dx.doi.org/10.2113/gsecongeo.65.3.253

[20] Sawlowicz, Z. (2000) Framboids: From Their Origin to Application. Prace Mineralogiczne, 88, 1-80.

[21] Roberts, F.I. (1982) Trace Element Chemistry of Pyrite: A Useful Guide to the Occurrence of Sulfide Base Metal Mineralization. Journal of Geochemical Exploration, 17, 49-62. http://dx.doi.org/10.1016/0375-6742(82)90019-X

[22] Bralia, A., Sabatini, G. and Troja, F. (1979) A Revaluation of the Co/Ni Ratio in Pyrite as Geochemical Tool in Ore Genesis Problems. Mineral Deposita, 14, 353-374.

[23] Huerta-Diaz, M.A. and Morse, J.W. (1992) Pyritization of Trace Metals in Anoxic Marine Sediments. Geochimica et Cosmochimica Acta, 56, 2681-2702. 